doi: 10.15330/apred.2.17.20-30

\title{
СВІТОВІ НОВІТНІ ПІДХОДИ ДО РЕСУРСНОГО ЗАБЕЗПЕЧЕННЯ АВТОНОМНОГО ОСВІТНЬОГО ПРОЦЕСУ
}

\author{
${ }^{1}$ Уманський державний педагогічний університет імені \\ Павла Тичини, \\ кафедра фінансів, обліку та економічної безпеки \\ вул. Садова, 2, м. Умань, \\ 20300, Україна, \\ тел.: 0677729730 , \\ e-mail: melnichyk_yuliya@ukr.net, \\ ORCID: 0000-0003-4149-0205
}

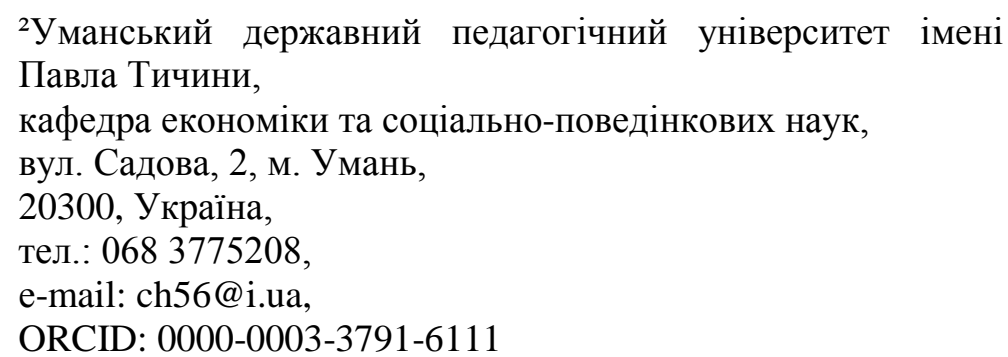

Анотація. У дослідженні на тему «Світові новітні підходи до ресурсного забезпечення автономного освітнього процесу» розглядається низка недавнього досвіду як із традиційними, так і з більш інноваційними механізмами розподілу ресурсів у всьому світі. Мета полягає в дослідженні перспективи інновацій та висвітленні досягнень, які можуть допомогти розробникам політики в країнах, що розвиваються, та країнах 3 перехідною економікою сформулювати стратегії підвищення ефективності їх державної політики щодо вищої освіти.

В праці описується розробка типології, що охоплює діапазон підходів до розподілу ресурсів для вищої освіти, що використовуються в даний час або розглядаються в різних країнах, у багатьох випадках документуючи шлях до інновацій, який все більше веде до механізмів, заснованих на підзвітності щодо основних результатів діяльності. Ця типологія включає не лише підходи, які безпосередньо фінансують установи, але й ті, що направляють кошти студентам.

Вирізнено основні причини стрімкого зростання попиту: економічна цінність здобуття вищої освіти практично у всіх країнах, що вимірюється показниками рентабельності чи іншими показниками, зростає швидше, ніж економічна віддача, що надходить тим, хто здобуває середню освіту або менше; у багатьох культурах існує сильний соціальний тиск на студентів 3 метою виходу за межі середнього рівня освіти 3 немонетарних причин, таких як більший соціальний статус та престиж у громаді; багато країн намагаються зробити свої програми вищої освіти більш актуальними, оскільки уряди та заклади вищої освіти децентралізують певні галузі $з$ низьким рівнем попиту на робочу силу, такі як державне управління та освіта, на користь нових сфер, таких як інформаційні технології, техніка та наука.

Проаналізовано різні механізми розподілу, на скільки вони відповідають важливим політичним цілям, таким як розширений доступ та поліпшення власного капіталу, підвищення внутрішньої ефективності та стримування витрат, а також результати, пов'язані із підвищенням якості та релевантності.

У праці розглядаються необхідні умови для ефективного впровадження інноваційних механізмів розподілу, включаючи необхідність посилення адміністративної спроможності, сприяння прозорості, вирішення політичних аспектів фінансових реформ та передбачення непередбачуваних наслідків. Запропоновано напрями досягнення автономії фінансування освіти та умови забезпечення такого фінансування. 
Актуальні проблеми розвитку економіки регіону. Вип 17. Т.2

Ключові слова: ресурсне забезпечення, фінансові ресурси, соціальні важелі, незалежний процес

\title{
Melnychuk Yu.M.1, Chyrva H.M. ${ }^{2}$ WORLD LATEST APPROACHES TO RESOURCE PROVISION OF AUTONOMOUS EDUCATIONAL PROCESS
}

\author{
1Pavlo Tychyna Uman State Pedagogical University, \\ Ministry of Education and Science of Ukraine, \\ Department of Finance, Accounting and Economic Security, \\ Sadova str., 2, Uman, \\ 20300, Ukraine, \\ tel.: 067 7729730, \\ e-mail: melnichyk_yuliya@ukr.net, \\ ORCID: 0000-0003-4149-0205 \\ 2Pavlo Tychyna Uman State Pedagogical University, \\ Ministry of Education and Science of Ukraine, \\ Department of Economics and Social Behavioral Sciences, \\ Sadova str., 2, Uman, \\ 20300, Ukraine, \\ tel.: 068 3775208, \\ e-mail: ch56@i.ua, \\ ORCID: 0000-0003-3791-6111
}

\begin{abstract}
The study on "World latest approaches to resource provision of autonomous educational process" examines a number of recent experiences with both traditional and more innovative mechanisms for resource allocation around the world. The aim is to explore the perspective of innovation and highlight achievements that can help policy makers in developing countries and countries with economies in transition to formulate strategies to improve the effectiveness of their public higher education policies.

The paper describes the development of a typology covering a range of approaches to the allocation of resources for higher education currently used or considered in different countries, in many cases documenting the path to innovation, which increasingly leads to mechanisms based on accountability for key performance. This typology includes not only approaches that directly fund institutions, but also those that send funds to students.

The main reasons for the rapid growth of demand are highlighted: the economic value of higher education in almost all countries, as measured by profitability or other indicators, is growing faster than the economic return to those who receive secondary education or less; in many cultures, there is strong social pressure on students to go beyond secondary education for non-monetary reasons, such as greater social status and prestige in the community; many countries are trying to make their higher education programs more relevant as governments and higher education institutions decentralize certain areas with low labor demand, such as public administration and education, to new areas such as information technology, technology and science.

Various allocation mechanisms are analyzed to the extent that they meet important policy objectives, such as increased access and improvement of equity, increased internal efficiency and cost containment, and results related to improving quality and relevance.

The paper considers the necessary conditions for the effective implementation of innovative allocation mechanisms, including the need to strengthen administrative capacity, promote transparency, address the political aspects of financial reforms and anticipate unpredictable consequences. The directions of achievement of autonomy of financing of education and conditions of maintenance of such financing are offered.
\end{abstract}

Key words: resource provision, financial resources, social levers, independent process 
Актуальні проблеми розвитку економіки регіону. Вип 17. T.2

Вступ. В останні десятиліття все більша кількість країн шукає інноваційні рішення значних проблем, з якими вони стикаються у фінансуванні вищої освіти. Однією з основних проблем $\epsilon$ те, що попит на освіту за середнім рівнем у більшості країн світу зростає набагато швидше ніж здатність чи готовність урядів надавати державні ресурси, достатні для задоволення цього попиту. Існує три основні причини стрімкого зростання попиту.

По-перше, економічна цінність здобуття вищої освіти практично у всіх країнах, що вимірюється показниками рентабельності чи іншими показниками, зростає швидше, ніж економічна віддача, що надходить тим, хто здобуває середню освіту або менше.

По-друге, у багатьох культурах існує сильний соціальний тиск на студентів 3 метою виходу за межі середнього рівня освіти 3 немонетарних причин, таких як більший соціальний статус та престиж у громаді.

По-третє, багато країн намагаються зробити свої програми вищої освіти більш актуальними, оскільки уряди та заклади вищої освіти децентралізують певні галузі 3 низьким рівнем попиту на робочу силу, такі як державне управління та освіта, на користь нових сфер, таких як інформаційні технології, техніка та наука.

Вимоги до державних ресурсів зростають більш інтенсивними темпами, оскільки уряди усього світу стикаються із загальновиробничими проблемами у забезпеченні більшої кількості та кращих державних послуг, включаючи охорону здоров'я, житло, транспорт, сільське господарство та повний спектр освіти. У цьому контексті вища освіта часто далека від найвищого пріоритету для державного фінансування як у промислових, так і в країнах, що розвиваються.

Країни та установи реагували на невідповідність між наявними державними ресурсами та зростаючим попитом на вищу освіту різними способами. Найчастішою реакцією була мобілізація більшої кількості ресурсів, головним чином шляхом запровадження або підвищення плати за навчання як способу збільшення розподілу витрат. Інша відповідна відповідь полягала у пошуку додаткових приватних ресурсів шляхом комерціалізації досліджень та інших приватних потреб інституційних установ та персоналу. Третьою, можливо рідше зустрічається відповіддю, стала посилена залежність від випуску облігацій та інших форм креативного фінансування, які дозволяють розширити державно-приватне партнерство у наданні послуг, пов'язаних 3 діяльністю вищої освіти.

Ця пропозиція зосереджується на тенденції до інноваційних механізмів розподілу коштів, які дозволяють як державним, так і приватним фондам піти далі у вирішенні проблем, 3 якими стикаються системи вищої освіти у всьому світі. Такі новаторські механізми охоплюють широкий спектр підходів, включаючи: еволюція механізмів передачі державних ресурсів для періодичних витрат та капітальних вкладень у ряді країн від більш традиційних переговорів про бюджети між урядами та державними установами до все більш досконалих формул фінансування, які мають на меті ізолювати рішення про розподіл коштів від надмірного політичного тиску та заохотити позитивну інституційну поведінку.

Створення системи ваучерів на стороні попиту, такої, як нещодавно запущена в штаті Колорадо (США), в якій інституційні субсидії на дію будуть розподілятися за допомогою ваучера, що видається всім студентам, або врахування можливого використання заохочення, подібне до ваучерів, шляхом розподілу коштів за формулами для закладів на основі характеристик студентів, підхід, який можна назвати «ваучерами на стороні пропозиції».

Такі системи можуть бути обмежені державними вищими навчальними закладами, але також можуть охоплювати студентів приватних установ. 
Актуальні проблеми розвитку економіки регіону. Вип 17. Т.2

Прийняття різноманітних механізмів розподілу за результатами діяльності в ряді країн обумовлені факторами:

- виділення частини фінансування для розподілу між установами на основі низки показників ефективності;

- контракти на виконання, укладені між урядами та установами;

-конкурентні фонди, що заохочують інновації, підвищення академічної якості та зміцнення інституційного потенціалу управління;

- механізми фінансування, які безпосередньо платять за результати, або як частина основної формули фінансування, або як окремий набір державних платежів установ;

- розробка альтернатив найбільш традиційному способу фінансування університетських досліджень, що спільно фінансує їх з інструктажами та операціями, включаючи підходи, які фінансують дослідження окремо від інструктажів;

- створення центрів досконалості досліджень у вибраних містечках та використання будь-якого 3 підходів "блакитного неба", що заохочує широкі експерименти у фундаментальних та прикладних дослідженнях.

Конкурентне фінансування на основі проектів фінансової допомоги студентам 3 високим рівнем фінансових потреб та академічними заслугами, щоб дозволити стратегії фінансування, щоб збільшити загальний рівень ресурсів для закладів та допомогти студентам оплатити своє житло, харчування та інші витрати на проживання під час навчання, включаючи надання допомоги студентам у формі ваучерів як засоби стимулювання більшої конкуренції між закладами та як альтернатива більш традиційним урядовим, але інституційно керованим, програмам допомоги студентам створення податкових пільг (кредитів, франшиз тощо) у ряді країн, щоб допомогти студентам та їхнім сім'ям компенсувати витрати на оплату за навчання та сімейні надбавки на основі податків, які в основному покривають витрати на життя, пов'язані 3 відвідуванням вищої освіти.

Зростання студентських позик у багатьох країнах спостерігається протягом багатьох років, щоб допомогти студентам оплачувати витрати на навчання, передбачені стратегіями відшкодування витрат на навчання та витрат на проживання, включаючи розробку графіків погашення доходів. Це здійснюється за умови, якщо виплати пов'язані з сумою запозичень та доходами позичальників після закінчення навчання.

Багато механізмів креативного фінансування все більше набувають розвитку. За допомогою таких способів здійснюється початкове фінансування іпотечного кредитування студентів, які здобувають освіту за допомогою сучасних методів фінансування.

Як вказує наведений вище перелік, пошук інноваційних механізмів стосується як фінансування установ, так і фінансування студентів. У випадку інституційної підтримки механізми розподілу застосовуються до фінансування навчання, операцій та капітальних вкладень, а також до університетських досліджень.

Що стосується підтримки студентів, механізми включають надання грантів та стипендій, використання податкових пільг для компенсації поточних витрат на оплату навчання та витрат на життя, а також постійне зростання залежності від студентських позик у багатьох країнах світу.

Постановка завдання. На основі вище зазначеного, можна зробити висновок, що досліджені типології описують як традиційні, так і інноваційні підходи до розподілу ресурсів, які використовуються або розглядаються в різних країнах. Типологія включає підходи, які фінансують установи безпосередньо та опосередковано через студентів, а також ті, що фінансують студентів та їхні сім'ї. 
Різні механізми розподілу відповідають важливим політичним цілям, таким як розширений доступ та поліпшення власного капіталу, краща зовнішня ефективність, така як підвищена якість та актуальність, а також підвищення внутрішньої ефективності за рахунок обмеження витрат та кращої пропускної здатності.

Тому, варто визначити різні умови, необхідні для успішного впровадження різних інноваційних підходів, що безумовно $є$ актуальним і необхідним для дослідження питанням сьогодення.

Основним завданням даної роботи є розгляд сфери та потенційного впливу різних інноваційних механізмів розподілу ресурсів. Такий огляд може допомогти політикам, керівникам інституцій та зацікавленим сторонам у вищій освіті визначити та дослідити найефективніші шляхи підвищення продуктивності та ефективності передачі державних ресурсів установам та студентам.

В процесі опрацювання матеріалів використовувалась сукупність методів дослідження, що становить методологію аналізу та організації основних законодавчих актів та законів, а саме методи узагальнення, порівняння, хронологізації, аналізу та узагальнення.

Результати. Уряди, як правило, надають державну підтримку університетам для двох основних цілей [1]:

- фінансування витрат на навчання, діяльність та інвестиції;

- виплати за проведення університетських досліджень, включаючи інвестиції у науково-дослідні установи та обладнання.

Уряди усього світу використовують ряд різних підходів, щоб допомогти вищим навчальним закладам оплачувати свої витрати, пов'язані з навчанням операціями та капітальними вкладеннями в академічні та пов'язані з ними приміщення та обладнання. Ці виплати, як правило, застосовуються лише до державних установ, хоча в деяких країнах, таких як Нова Зеландія та Чилі, деякі приватні установи також мають право на державні форми інституційної підтримки. Вивчаючи механізми, що підтримують інституційну діяльність, важливо розрізняти, як визначається рівень державного фінансування вищої освіти та як ці державні кошти розподіляються.

Рішення про рівень фінансування може прийматись кількома способами, включаючи:

- конституційні положення;

- законодавство про асигнування;

- переговори між ключовими державними політиками та зацікавленими сторонами.

Для підтримки цих основних видів діяльності країни традиційно використовують варіанти наступних трьох механізмів розподілу:

- переговорні або спеціальні бюджети;

- категоричні або цільові кошти ;

- формули фінансування.

Переговорний або спеціальний бюджети - переговори між державними та вищими навчальними закладами є найбільш традиційним способом розподілу коштів на операційні та інвестиційні плани державних провайдерів між окремими установами. Рівні фінансування, визначені в ході переговорного процесу, як правило, головним чином, базуючись на історичних тенденціях, зазвичай розподіляються між установами одним із двох наступних способів [2]:

1. Бюджетні статті - узгоджені бюджети дуже часто виконуються шляхом розподілу позиційних установ. Зазвичай ці рядки включають відносно жорсткі обмеження щодо того, як установи можуть витрачати державні кошти, які вони отримують від урядів чи інших державних органів. Ступінь того, наскільки установи 
можуть переключатись або перерозподіляти бюджетні статті в деяких випадках, контролюється централізовано, тоді як в інших випадках установи мають більший розсуд.

2. Блок-гранти - надання єдиного блок-гранту кожній установі є ще одним способом реалізації узгоджених бюджетів. Блок-гранти, як правило, надають установам більшої гнучкості та автономії, ніж домовленості про позиції при визначенні витрат державних коштів.

Непал є прикладом країни, яка в даний час розглядає можливість переходу від бюджетної статті до блок-грантового фінансування в рамках реформи, спрямованої на надання вищим навчальним закладам більшої автономії. 3 іншого боку, Австралія нещодавно прийняла реформи, які рухаються в зворотному напрямку: в обмін на підвищення рівня державного фінансування протягом декількох років університетські чиновники погодились відійти від блокових грантів до більш регламентованого підходу до позицій.

Країни, які розглядають можливість переходу від позиційного фінансування до фінансування 3 грантовим фінансуванням, повинні враховувати різні закони та нормативні акти, які можуть потребувати коригування для забезпечення такого кроку. У деяких країнах переговорний процес відбувається в рамках бюджету, розрахованого на основі встановлених настанов. Наприклад, у кількох країнах Центральної Америки та Болівії, Перу, Еквадору, Конституція передбачає, що державні університети повинні отримувати від 5 до 7 відсотків національного бюджету щороку. У Коста-Ріці асигнування на вищу освіту визначаються у відсотках від ВВП. В Йорданії бюджет університетів представляє певний відсоток імпортних та експортних операцій.

Розглянемо категоричні або цільові кошти. Категоричні фонди - ще один традиційний спосіб розподілу державних коштів на вищі навчальні заклади. Вони, як правило, передбачають призначення урядом або „призначенням” певної установи чи групи установ для отримання коштів на певні цілі. Часто категоричні або цільові фонди створюються для спроби виправити або покращити реальне або сприйняте минуле недофінансування для групи установ, що найчастіше характеризується їх географічним розташуванням або типом студентів, яких вони обслуговують.

Наприклад, установи, розташовані у сільській місцевості, можуть бути визнані урядом як такі, що мають право на отримання коштів для розширення можливостей дистанційного навчання. Або установи, які обслуговують велику кількість студентів із хронічним недоліком, можуть отримати право на отримання грантів на модернізацію своїх приміщень чи обладнання. США та Південна Африка є прикладами країн, які використовували категоричні кошти для цієї останньої мети. У США така програма впродовж десятиліть доводить, що виділяють кошти на установи, які обслуговують значну частку студентів меншин. У Південній Африці категоричні фонди для бібліотек, навчальних закладів та обладнання були відведені для переважно темношкірих закладів до того, як відбулося широке злиття [3].

Досвід показує, що категоріальні фонди найкраще підходять для спрямування коштів на конкретні установи чи групи установ з визначеним набором потреб, особливо на конкретні фізичні ресурси або послуги, такі як бібліотеки чи лабораторії. Розподіл цільових коштів серед установ, що беруть участь, може бути здійснено одним із кількох способів: розподіл може бути визначений у законодавстві на основі оцінки потреби у визначених видах діяльності чи послуг, або на основі зарахування чи іншої основи формули. Як правило, категоричні фонди, здається, більше підходять для фінансування інвестиційних проектів, ніж операційні видатки.

Категоричні фонди також можуть бути особливо корисними для фінансування діяльності, в якій вигоди перекидаються за межі університету та його студентів на 
ширшу спільноту. 3 іншого боку, категоричні фонди мають той недолік, що впливають лише на ті установи, які мають право на фінансування. Інституції, які не мають права на цільові цілі, мають незначний стимул або зовсім не стимулюють його вдосконалювати чи виконувати визначені державні пріоритети, оскільки їм не дозволяється конкурувати за кошти.

Розглянемо вид фінансування як формули фінансування. 3 часом багато урядів відійшли від узгоджених бюджетів та спрямували кошти на певний тип формули як основний засіб розподілу коштів установам на їх постійні витрати. Ці формули варіюються залежно від факторів, що використовуються при їх розробці, і типу організації, яка розробляє формулу. Приклади факторів, які часто використовуються для визначення формул фінансування, включають [4]:

1. Вклади, такі як персонал або студенти - більшість формул фінансування, принаймні частково, базуються на вкладах у формі персоналу чи студентів. Формула найбільш елементарного типу фінансування використовує кількість персоналу або зарплату персоналу в кожному закладі як основу для розподілу коштів.

Непал $є$ прикладом країни, яка в даний час використовує таку формулу фінансування. Іноді застосовуються більш вишукані заходи на основі персоналу, такі як кількість професорів, які мають ступінь доктора філософії. Формули, засновані на персоналі, досі використовуються багатьма урядами, особливо у Східній Європі. Оскільки дебати щодо фінансування з часом ускладнювались, розробники формул, як правило, переходили до використання кількості студентів, а не кількості чи кваліфікації персоналу як основи розподілу коштів. Кількість студентів може бути розрахована на перспективній або ретроспективній (фактичній) основі. Ретроспективні розподіли за своєю природою, як правило, більше базуються на фактичних даних, тоді як перспективні формули, як правило, вимагають коригувань у середині року, щоб відобразити реальність повернення платежів. У деяких випадках формули на основі персоналу комбінують з формулами, заснованими на кількості зарахованих студентів [3].

Наприклад, у Польщі розподіл заснований на поєднанні кількості зарахованих студентів та кількості штатних викладачів з докторами наук. Одне 3 найважливіших питань, яке повинні прийняти політики вирішити, використовуючи системи формул, що базуються на реєстрації, полягає в тому, як визначити, яке навантаження на курс становить повний робочий день, і як розрізнити студентів на денній та заочній формах. Існує велика різноманітність у тому, як країни вирішують ці питання, хоча майже у всіх випадки студентів денної форми навчання, як би вони не були визначені, отримують іншу вагу, ніж студенти заочної форми навчання, при обчисленні витрат на одного студента, співвідношення студент - викладачі та інші показники [4].

Іншим ключовим питанням у розробці систем розподілу на основі зарахування $\epsilon$ обмеження кількості студентів, які будуть фінансуватися. Більшість країн обмежують кількість студентів, яких вони фінансуватимуть головним чином за допомогою процесу планування як засобу для контролю за бюджетним ризиком. У кількох країнах існує система фінансування, що базується на попиті, в якій обмеження фінансування не встановлюються, і всі кваліфіковані студенти фінансуються, хоча часто вони мають нижчий рівень витрат на одного студента, ніж це застосовується за обмеженою системою. Нова Зеландія $\epsilon$, мабуть, найвидатнішим прикладом такої системи фінансування, що керується попитом, хоча бюджетні реалії призводять до перегляду цих відкритих домовленостей.

2. Домовленості про повернення коштів - коли формули фінансування грунтуються на перспективних оцінках кількості студентів та витрат, механізми повернення коштів дозволяють переглядати початкові асигнування в середині року або 
після них, щоб відобразити фактичні рівні витрат, і тоді фінансування може бути скориговане. Більшість країн, які використовують формули, засновані на перспективній кількості студентів, тепер визнають, що їм слід використовувати зворотні платежі для виправлення помилкових прогнозів кількості студентів або витрат на одного студента. Цей вид корекції середнього курсу суттєво зменшує обсяг учасників, який, ймовірно, може відбутися, коли посадовці закладу попросять оцінити цифри на майбутній рік, а не звітувати про фактичне зарахування або витрати на одного студента у попередньому році. Інший підхід полягає в тому, щоб уряд чи орган фінансування приймав участь у проектах і ризикував неправильним проектуванням. Це зменшує потенціал для "ігор", одночасно дозволяючи зростати. Південна Африка використовує такий запланований підхід [5].

3. Витрати на студента - більшість формул фінансування зараз базуються на певному показнику кількості студентів, записаних у певний момент часу, помноженому на розрахунок вартості на студента. Витрати на одного студента, як правило, розраховуються ретроспективно 3 очевидної причини - заклади не повинні фінансуватись на основі витрат, які, на їх думку, вони понесуть і базуються на одній 3 кількох цифр зарахування.

Фактичні витрати на одного студента - найбільш традиційна форма фінансування формул відбувається тоді, коли розподіл коштів на установи базується на фактичних витратах на одного студента, як повідомляє заклад. Більшість штатів США використовують у формулах фінансування фактичні витрати на одного студента; багато країн також прагнуть використовувати фактичні витрати при розрахунку своїх інституційних асигнувань [3].

Середні витрати на студента - у цьому підході, який $є$ альтернативою використанню фактичних витрат на студента в кожному закладі, розподіл коштів на заклади базується на загальносистемних середніх витратах на студента, як правило, обчислюваних із сукупної статистики витрат та зарахування.

Нормативні витрати на студента - мабуть, найбільш інноваційним способом розрахунку витрат на студента у формулах фінансування є базування розрахунку на нормативних витратах. Відповідно до цього підходу для розрахунку витрат на одного студента використовуються оптимальні співвідношення персонал-студент та інші стандартизовані міри ефективності, якими вони є на дійсній або середній основі. Таким чином, формули, що використовують нормативні витрати, мають потенціал для підвищення ефективності, пов'язуючи, скільки установ будуть платити за свої витрати, до стандарту, що базується на більшій ефективності.

Серед промислових країн Англія є однією 3 основних країн, де нормативні витрати стали частиною розрахунку формули фінансування. Часто за наполяганням Світового банку нещодавно нормативні витрати були введені у формули фінансування також у ряді країн, що розвиваються та країн з перехідною економікою, наприклад, у Болгарії, Угорщині та Чехії [2].

Порівняльний аналіз є однією з форм нормативних витрат, яка використовується в деяких країнах, $\epsilon$ така, при якій показники витрат і структура прив'язуються до «базового» закладу або набору установ. Ряд штатів США, наприклад, Кентуккі, використовують структуру витрат подібних установ в інших штатах, щоб допомогти встановити витрати на одного студента у своїх формулах фінансування [6].

4. Пріоритетне фінансування - ще однією базою фінансування є та, при якій вносяться корективи до міркувань, що базуються на витратах, щоб відобразити національні та регіональні пріоритети, такі як критичні потреби у робочій силі. Цей підхід також можна назвати «фінансуванням актуальності», оскільки галузі навчання, визначені як найбільш актуальні, як правило, отримують найвищий рівень коштів. 
Традиційний спосіб фінансування актуальності відбувається тоді, коли центральні органи визначають, які програми фінансувати, виходячи зі свого визначення відповідності. У рамках більш інноваційного підходу, який зараз застосовується в деяких країнах, «ціна», яку уряд чи орган фінансування надає установам за місце у високопріоритетному напрямі, вища, ніж те, що платять за місця в галузях нижчого пріоритету. У деяких випадках повна вартість на студента або навіть більше може бути сплачена установам за місця, визначені як такі, що мають пріоритетний напрямок навчання. Або виплати можуть бути збільшені для тих установ, які вважаються пріоритетними, ніж інші установи.

Наприклад, установам у сільській місцевості можуть платити більше за місця, ніж більшим міським установам, якщо існує бажання забезпечити більш розпорошений розподіл студентів. Спеціальні гранти на душу населення для студентів 3 «предметів дефіциту», що використовуються в Англії, є одним із прикладів фінансування за пріоритетом [3].

5. Продуктивність заснована на формулі компонентів - інший нетрадиційний підхід до фінансування виникає, коли показники ефективності інститутів вбудовуються у формулу фінансування, наприклад, шляхом оплати навчальних закладів на основі кількості осіб, які закінчують навчання в кінці року, або одержувачів ступенів, а не кількості зарахованих студентів. Цей підхід детальніше обговорюється нижче в розділі про фінансування на основі результатів.

Міжнародний досвід роботи 3 конкурентними фондами показав необхідність врахування трьох оперативних питань при розробці нового фонду [6]:

- Як створити рівні умови в диверсифікованих системах із сильними та слабкими вищими навчальними закладами?

- Чи мають право приватні установи брати участь?

- Чи варто тісно пов'язувати доступ до фінансування 3 акредитацією чи подібними вимогами щодо забезпечення якості?

Для вирішення неоднорідності установ та потенціалу може бути вагомим аргументом для відкриття декількох вікон фінансування 3 різними критеріями прийнятності та лімітами фінансування, або для встановлення компенсаційних механізмів для збільшення власного капіталу серед установ 3 різним рівнем спроможності. Наприклад, в Індонезії три різні вікна конкуренції були розроблені для обслуговування університетів відповідно до їх фактичної інституційної спроможності. Це рішення допомогло не допустити, щоб найсильніші установи виграли все фінансування, а слабкі заклади залишили поза грою і не змогли використати значні державні ресурси для важливих інвестицій у покращення якості.

У нещодавньому проекті вищої освіти в Китаї, найсильніші університети 3 найбільшими можливостями повинні були створити партнерські відносини із слабшим університетом, який знаходиться в бідній провінції, як умова для конкуренції за ресурси з фонду реформи навчальної програми.

В Єгипті в конкурсному фонді, ініційованому в рамках проекту реформи інженерної освіти, який підтримується Світовим банком, було спеціальне вікно для технічної допомоги, щоб допомогти менш досвідченим інженерним школам підготувати чітко сформульовані пропозиції. Також в Єгипті пропозиції, які включали угоду про партнерство між сильнішим та слабшим університетами, отримали додаткові бали для цілей оцінки.

У Чилі нещодавно було відкрито спеціальне віконце для надання коштів на підготовку університетів, які потребують допомоги у стратегічному плануванні та формуванні підпроектів. 
Уряди, які хочуть заохотити зростання високоякісних приватних установ, можуть використовувати конкурентні кошти для підтримки інвестицій у ці установи. Конкурентний фонд для інженерної освіти на Філіппінах мав цю особливість у 1980-х роках, а постійні інноваційні фонди в Шрі-Ланці, Чилі та Гані роблять державні ресурси доступними для приватних установ.

Висновки. Однією з сильних сторін конкурентних фондів $є$ те, що вони, швидше за все, будуть ефективнішими для підвищення якості, ніж ширші підходи, такі як узгоджені бюджети або формули фінансування. Отже, один із способів покращення якості конкурентних фондів полягає у встановленні посилань виплата коштів для участі в процесі акредитації на добровільній основі (Аргентина) або в обов'язковому порядку (Чилі). Інший підхід полягає у використанні покращення якості як критерію при оцінці пропозицій та відборі одержувачів.

Прикладами країн, які врахували ефективність своїх формул фінансування, є: Англія, де формула періодичних витрат оплачується на основі кількості студентів, які закінчують кожен рік навчання; Данія, яка має «модель таксометра», в якій за кожного студента, який склав іспити, виплачується від 30 до 50 відсотків періодичних коштів; Нідерланди, де половина періодичного фінансування базується на кількості присуджених ступенів; Південна Африка, де формула фінансування враховує як кількість зарахованих студентів, так і кількість випускників; та Норвегія, де деяке фінансування базується на кількості отриманих кредитів, і частина фінансування буде базуватися на кількості випускників.

Виплати за результати можуть також здійснюватися поза звичайною формулою фінансування. Наприклад, у штаті Колорадо (США) штат через контракт про оплату послуг закуповує певну кількість годин, що субсидуються, для студентів-резидентів, щоб доповнити схему ваучерів для студентів. Інший вид оплати за результати здійснюється в рамках системи громадських коледжів у США та Канаді, за допомогою якої уряд укладає контракти з приватними фірмами на навчання працівників.

Освіта в Україні знаходиться в стані удосконалення, шлях фінансування закладів освіти, який вибере влада, залежить від багатьох факторів, згаданих вище. Саме тому, всесвітній досвід допоможе прийняти оптимальні рішення і зберегти розвиток освітянського процесу країни.

1. Melnychuk Y., Tkachuk I., Tkachuk Yu., Solodzhuk T., Kyryluk I. Economic Mechanism for Managing the Strategic Development of Territorial Communities. Tem Journal. 2020. Vol. 9. № 4. Pp. 1606-1613.

2. Who Should Pay: Tuition Fees and Tertiary Education Financing in New Zealand? Research Gate. URL: https://www.researchgate.net/figure/Growth-in-tertiary-education-participation-in-New-

Zealand_fig1_348851119 (дата звернення: 01.09.2021)

3. What is Education Finance? Education Finance. URL: https://www.edu-links.org/learning/whateducation-finance (дата звернення: 03.09.2021)

4. The Top Technology Innovations for Education. The Ame Group. URL: https://www.theamegroup.com/top-6-technology-innovations-education/ (дата звернення: 03.09.2021)

5. Serdyukov P. Innovation in education: what works, what doesn't, and what to do about it? Journal of Research in Innovative Teaching \& Learning. 2017. Vol. 10. № 1. Pp. 4-33.

6. Heick T. Examples Of Innovation In Higher Education. URL: https://www.teachthought.com/the-futureof-learning/examples-of-innovation-in-higher-ed/ (дата звернення: 05.09.2021)

\section{References}

1. Melnychuk, Y., Tkachuk, I., Tkachuk, Yu., Solodzhuk, T., and I. Kyryluk. "Economic Mechanism for Managing the Strategic Development of Territorial Communities.” Tem Journal, vol. 9, no. 4, 2020, pp. 1606-1613.

2. "Who Should Pay: Tuition Fees and Tertiary Education Financing in New Zealand?” Research Gate, www.researchgate.net/figure/Growth-in-tertiary-education-participation-in-New-

Zealand_fig1_348851119. Accessed 01 Sept.2021. 
Актуальні проблеми розвитку економіки регіону. Вип 17. Т.2

3. “What is Education Finance?” Education Finance, www.edu-links.org/learning/what-education-finance. Accessed 03 Sept.2021.

4. "The Top Technology Innovations for Education." The Ame Group, www.theamegroup.com/top-6technology-innovations-education/ Accessed 03 Sept.2021

5. Serdyukov, P. “Innovation in education: what works, what doesn't, and what to do about it?” Journal of Research in Innovative Teaching \& Learning, vol. 10, no. 1, 2017, pp. 4-33.

6. Heick, T. "Examples Of Innovation In Higher Education." Teachthought, www.teachthought.com/thefuture-of-learning/examples-of-innovation-in-higher-ed/ Accessed 05 Sept.2021. 